\title{
KARS VE ERZURUM AĞIZLARINDA RUSÇA ÖDÜNÇ KELIMELER*
}

\author{
Muharrem DAŞDEMIR** \\ Süleyman EFENDİOĞLU ${ }^{* * *}$
}

$\ddot{O} \mathbf{z}$

Türkiye'de Kars ve Erzurum yöresi uzun yıllar Rusya ile tarihî, siyasi, sosyal ve kültürel iliş̧kiler içerisinde olmuştur. Bu iliş̧kiler doğal olarak dile de yansımıştır. Makalede Kars ve Erzurum yöresi ağızlarında tespit edilen Rusça kökenli ödünç kelimeler üzerinde durularak bugün bile Doğu Anadolu sahasında yaşamını devam ettiren bu Rusça ödünç kelimeler vasıtasıyla Türkçe-Rusça arasındaki dil-kültür münasebetleri irdelenmeye çalışlacaktır.

Anahtar Sözcükler: Kars ve Erzurum ağızları, Rusça kökenli ödünç kelimeler, Türkçe-Rusça dil iliş̧isi.

\section{RUSHIAN BORROWED WORDS IN KARS AND ERZURUM DIALECTS}

\begin{abstract}
Some region of Turkey, particularly Kars and Erzurum regions have had historical, political and social relations with Russia for many years. As a matter of course, these relations have influenced the language. In this paper, we focus on the Russian origin borrow words which were detected in dialect of Kars and Erzurum regions. So, linguistic story of these borrowed Russian words that still available in Eastern Anatolia Region is exhibited and language-culture relations between Turkish and Russian are analyzed.
\end{abstract}

Keywords: Kars and Erzurum dialects, Russian origin borrow words, Turkish-Russian language relations.

Milletlerin tarih içinde vuku bulan siyasi ve kültürel temasları, dilde mutlaka yansımasını bulur. Bundan dolayı diller, karşı1ıklı kültür nüfuzlarının boyutlarını belirlemeye yarayan iyi bir belge niteliğindedir. ${ }^{1}$

Kültürel alışverişlerin dildeki yansımaları ise daha çok söz varlı̆̆ı (İng. vocabulary) düzeyinde olur. ${ }^{2}$ Bir dilden bir dile sözcük transferi gayet kolay ve doğaldır: Bir millet, yazı veya konuşma dili yoluyla temasta bulunduğu bir kültürden yeni bir kavram öğrendiğinde kavramla birlikte onun ismini de alır. Hatta dil kullanıcıları, hiç ihtiyaç olmasa da tamamen

\footnotetext{
* Bu makale, 11-14 Eylül 2014 tarihleri arasında Rusya'nın Petersburg şehrinde düzenlenen V. European Conference on Social and Behavioral Sciences adlı konferansta sunulmuş ancak yayımlanmamış olan bildirimizin gözden geçirilerek yeniden düzenlenmiş hâlidir.

** Prof. Dr.; Atatürk Üniversitesi Edebiyat Fakültesi Türk Dili ve Edebiyatı Bölümü, muharremdasdemir@atauni.edu.tr.

*** Doç. Dr.; Atatürk Üniversitesi Edebiyat Fakültesi Çağdaş Türk Lehçeleri ve Edebiyatları Bölümü, sefendioglu@atauni.edu.tr.

${ }^{1}$ Bazın, 1992, s. 1.

${ }^{2}$ Aksan, 1990, s. 27.
} 
$160^{*}$ TAED 55

Muharrem DAŞDEMIR - Süleyman EFENDiOĞLU

psikolojik etkenlerle (moda, dinsel kaygılar vs.) kendi dillerinde mevcut olan bir sözcügü terk edip onun yabancı dildeki karşılığını tercih edebilirler. Alıcı durumundaki dil, "oluş, kılış ve nitelikleri karşılayan sıfat, zarf ve fiillerden çok nesneleri karşılayan isimleri" kendi söz varlığına dâhil eder. ${ }^{3}$ Zarf, sıfat, edat vs. türünden sözcüklerin ödünçlenmesi ise, yankatman (İng. adstratum), altkatman (İng. substratum), üstkatman (İng. superstratum) ilişkileriyle dilsel etkileşimin ileri düzeye vardığı durumlarda görülür. Fakat yabancı dillerin birbirine etkisi söz varlığı ile sınırlı değildir: Dilsel etkileşim, ses bilgisini (İng. phonetics), biçim bilgisini (İng. morphology), söz dizimini (İng. syntax) etkileyecek düzeye de ulaşabilir. Örneğin, Tacikistan'da İranlılarca konuşulan Tacik dili, Türkçenin Özbek lehçesinden o kadar etkilenmiştir ki bu durum, G. Doerfer tarafından "Doğuş hâlindeki bir Türk dili" olarak nitelendirilmiştir. $^{4}$

Aslında diller arasındaki etkileşim insanlık tarihiyle yaşıt olmalıdır. Yeryüzündeki bütün diller ihtiyaç duydukları, çoğu zaman kendi dillerinde bulunmayan bazı sözcükleri birbirlerinden almışlardır. Bu şekilde yabancı dillerden sözcüklerin, deyimlerin ve terimlerin alınması ödünçleme (İng. alienism, borrowing) olarak adlandırılmaktadır. Bu tür sözcüklere de ödünç sözcük, alınma sözcük, alıntı, alıntı sözcük, misafir sözcük, yabancı kökenli sözcük gibi adlar verilmektedir. Yeryüzündeki bütün diller, şu ya da bu ölçüde başka dillerle sözcük alışverişinde bulunmuşlardır. ${ }^{5}$

$\mathrm{Bu}$ açıdan Türkçe, tarih boyunca yabancı dillere karşı çok müsamahalı olmuştur. Türkler temasta bulundukları her milletten öğrendikleriyle kavram dünyalarını geliştirmiş ve bunu büyük oranda söz varlıklarında belgelemişlerdir. ${ }^{6}$ Ancak bu hoşgörünün bir dönem Arapça ve Farsçaya karşı aşırılığa vardığı, Türkçenin gramerini bozma noktasına geldiği bilinmektedir. Neyse ki "Yeni Lisan" hareketiyle başlayıp" son zamanlara kadar devam eden sadeleşme akımı bu dengesiz alışverişin önünü alabilmiştir. ${ }^{8}$ Sadeleşme akımı, sadece Arapça, Farsça, Fransızca ve İngilizce dilsel etkilere karşı yürütülmüş; konuşma dili yoluyla ve tamamen tabi bir seyir içinde diğer yabancı dillerden (Rumca, Rusça, İtalyanca, Ermenice, Moğolca vs.) Türkçeye geçmiş sözcüklere dokunulmamıştır.

\footnotetext{
${ }^{3}$ Gemalmaz, 1997, s. 3.

${ }^{4}$ Aksan, 1990, s. 139.

${ }^{5}$ Eker, 2010, s. 175.

${ }^{6}$ Aksan, age., s. 47-49.

${ }^{7}$ Öksüz, 1995, s. 77.

${ }^{8}$ Ediskun, 1992, s. 47.
} 
Türk Dil Kurumunun açıkladığı son istatistiki bilgilere göre Türkçedeki alıntı sözcüklerin sayısı aşağıdaki gibidir?

\begin{tabular}{l|l|l|l}
\hline Arapça 6516 & Fransızca 5540 & Farsça 1375 & İtalyanca 607 \\
\hline İngilizce 518 & Rumca 448 & Almanca 105 & Latince 68 \\
\hline Rusça 39 & Yunanca 37 & İspanyolca 31 & Ermenice 24 \\
\hline Bulgarca 22 & Macarca 15 & Japonca 13 & Moğolca 12 \\
\hline İbranice 8 & Fince 2 & Malayca 2 & Portekizce 2 \\
\hline Soğdca 2 & Arnavutça 1 & Fince 1 & Korece 1 \\
\hline Sırpça 1 & Slavca 1 & & \\
\hline
\end{tabular}

Türkçe yabancı dillerden kelime aldığı gibi tarih boyunca pek çok dile de çok sayıda kelime vermiştir. Yine Türk Dil Kurumunun verilerine göre Türkçeden başka dillere geçmiş kelimelerin sayısı şu şekildedir ${ }^{10}$ :

\begin{tabular}{l|l|l|l}
\hline Sirpça 9000 & Ermenice 4262 & Bulgarca 3500 & Rumence 3000 \\
\hline Farşa 3000 & Arnavutça 3000 & Yunanca 3000 & Rusça 2500* \\
\hline Arapça 2000 & Macarca 2000 & Ukraynaca 800 & İngilizce 470 \\
\hline Çince 300 & Çekçe 248 & Urduca 227 & Almanca 166 \\
\hline İtalyanca 146 & Fince 118 & Fransizca 100 & \\
\hline
\end{tabular}

Ödünçlemeler çoğu zaman sosyal, siyasal ve kültürel etkileşimin bir sonucudur. Türkiye'de Kars ve Erzurum ağızlarının dâhil olduğu Kuzeydoğu Anadolu Bölgesi söz varlığını en çok etkileyen yabancı diller Arapça, Farsça, Rumca, Rusça ve Ermenicedir. ${ }^{11}$ Doğrudan ilişki içerisinde bulunmuş olan komşu yabancı diller, bir dilin ağızlarını ses, şekil, söz varlığı veya cümle yapısı yönüyle etkileyebilir. Ancak Türkiye Türkçesi ağızlarında bu etkinin daha çok ses, şekil ve söz varlığı yönünde olduğu görülmektedir. Leylâ Karahan Türkiye Türkçesi ağızlarını sınıflandırırken, komşu dillerden Arapça ve Farsçanın etkisini göz önünde bulundurmuştur. Türkiye Türkçesi ağızlarında etkili olan bir diğer komşu dil ise Rusça olmuştur. Birbirine yakın coğrafyada yaşayan iki millet arasındaki derin ilişkiler, Rusçada, Türkçede ve bu dillerin lehçe ve ağızlarında kaçınılmaz olarak izler bırakmıştır. ${ }^{12}$

Türkiye'nin Doğu Anadolu Bölgesinin kuzeydoğu kesiminde yer alan Kars ve Erzurum şehirleri ülkenin doğudaki iki önemli serhat şehri olmalarının yanında bünyelerinde barındırdıkları kültür mozaiği ile de dikkat çekmektedirler. Geçmişten günümüze Türkiye'nin doğudaki iki önemli kalesi ve iki önemli sınır şehri konumunda bulunan Kars ve Erzurum, tarih içinde birçok ülkeyle de (Rusya, Gürcistan, Ermenistan, İran) komşu durumuna gelmişlerdir.

\footnotetext{
${ }^{9}$ Türk Dil Kurumu, 2011, s. 2674.

${ }^{10}$ bk. Güllüdağ, 2009, s. 237-250.

* Yukarıda verilen tablolarda Rusçadan alınan 39 kelimeye karşın Türkçenin Rusçaya 2500 kelime kazandırdığ görülmektedir. Ancak Rusçadan Türkçeye geçen kelimelere diğer Türk lehçe ve ağızlarını da kattığımızda bu sayının çok daha fazla olacă̆

${ }^{11}$ Gemalmaz, 1995, s. 377-379.

12 Özeren, 2014, s. 1093.
} 
Yine söz konusu bölge, tarih boyunca birçok medeniyete ve etnik gruba ev sahipliği yapmış; Orta Asya'dan gelen kavimlerin de geçiş ve kesişme yeri olmuştur. Bütün bunların neticesinde ise Kars-Erzurum bölgesinde bir kültür ve dil tabakalaşması meydana gelmiş; böylece bugün bölgede zengin bir folklor, renkli bir halk edebiyatı yanında zengin bir söz varlığı ortaya çıkmıştır. ${ }^{13}$

Erzurum ve Kars ağızlarını Rusça ödünç kelimeler açısından incelediğimizde pek çok Rusça sözcüğe rastlıyoruz. Ancak Rusça alıntı kelimelerin önemli bir kısmının askerî terimlerden oluştuğunu gözlemliyoruz. Bu durum, tarihî Türk-Rus komşuluk ilişkilerini hatırlatmakla birlikte bölgenin jeopolitik önemini de öne çıkarıyor. Özellikle son iki asır içerisinde meydana gelen Osmanlı-Rus savaşlarının ve bölgedeki Rus işgallerinin bölge ağızlarında ciddi bir tesir oluşturduğu aşikârdır. Bilindiği üzere tarihte 93 Harbi diye bilinen 1877-1878 Osmanlı Rus savaşlarının neticesinde Kars yaklaşık 40 yıl Ruslarca yönetilmiştir. Erzurum ise Birinci Dünya Savaşı sırasında iki yıl (1916-1918) Rus işgali altında kalmıştır. Bu dönemlerin neticesi olmak üzere bölge ağızlarına birçok Rusça ödünç kelime yerleşmiştir. Ayrıca 93 Harbi'nin ardından Rusya tarafından Kars civarına yerleştirilen Malakanların ${ }^{14}$ da bölge ağızları üzerinde etkisi olduğunu düşünüyoruz. Aşağıda Türkçe-Rusça dil ilişkileri, tarihî süreç içerisinde ele alınıp genel hatlarıyla belirlenmeye çalışılmıştır.

\section{Türkçe-Rusça Dil İlişkileri}

Türklerin Çinliler, Farslar ve Araplardan sonra en eski komşuları başta Ruslar olmak üzere Slav irklarıdır. MS 4. yüzyıllarda İndo-Germen topluluğundan ayrılan Kuzey ve Güney Slavları, MS 6. yüzyıldan itibaren önce Avarların sonra da Bulgar Türklerinin ziraatçı tebaaları olarak daha doğuya çekilmişler ve nihayet MS 8. yüzyıllarda bugünkü vatanlarına ulaşmışlardır. Bu sebeple gerek Kuzey Slavları gerekse Güney Slavları bu bin beş yüz yılı aşkın süre içinde daima bir Türk kavminin komşusu oldular. ${ }^{15}$

\footnotetext{
${ }^{13}$ Ercilasun, 2002, s. 11-46; Gemalmaz, 1995, s. 6-39.

14 "Molokane", "Molokanizm", Ortodoks Kilisesi'nden ayrılmış bir tarikattır. Hristiyanlığın bir türü, aynı zamanda Rusların özel etnik grubudur. Çarlık İmparatorluğu döneminde "çok zararlı tarikat" olarak bilinmişlerdir. 1682 yılında Ortodoks Kilisesi'nden ayrılan bu topluluk önce Kafkasya'nın kuzeyine daha sonra da Osmanlı ve İran sınırları boyunca Tiflis, Erivan ve Bakü eyaletlerine yerleștirildi. 1876-1877 Osmanlı-Rus Savaşları'nın ardından, Ruslar tarafindan Kars'a yerleştirilen bu insanlar uzun yıllar burada kaldıktan sonra başta ABD ve Avustralya olmak üzere diğer ülkelere yerleşmişlerdir.Türkiye'de Kars'ta ve İstanbul'da yaşamaktadırlar. Sürekli süt içtiklerinden kendilerine süt içen anlamında Rusça Molokan adı verildiği söylenmektedir. (http://tr.wikipedia.org/wiki/Malakanlar, http://ru.wikipedia.org/wiki/ Молокане)

${ }^{15}$ Karaağaç, 2008, s. XXIII.
} 
Esasında Slav dillerinin Türk lehçeleriyle ilişkileri pek eski çağlarda başlar. Rus kabileleriyle Türk kabileleri -Bulgarlar, Hazarlar, Peçenekler- arasındaki ilişkiler hakkında ilk yazılı bilgiler X. yüzyıldan kalma Rus ve Bizans kaynaklarında bulunur. Rusların Türk halklarıyla sıkı ilişkilerde bulunması, komşu göçebe kabilelerin askerî akını, komşu Türk ordularıla ortak askerî seferler, sadece bu iki ulusun birbirlerinin dillerini pratik amaçlarla öğrenmesini değil; aynı zamanda Rusça-Türkçe dil ilişkisini ve bunun neticesinde iki dilin birbirlerinden kelime alışverişinde bulunmasını zorunlu kılmıştır. Böylece, Slav dillerinden -genellikle Rusçadan- Türk lehçelerine ve Türk lehçelerinden de Slav dillerine kelimelerin geçmesi, askerî çarpışmalar, ortak askerî seferler, sıkı komşuluk ilişkileri, erken ticarî ilişkiler ve yoğun kültürel ilişkilerin bir sonucu olarak karşımıza çıkar. ${ }^{16}$

Slav ve Türk kabileleri ve halkları pek eski çağlardan günümüze kadar Asya'da ve Avrupa'da yaşamış, bugün de ayrı halklar hâlinde yaşamaya devam etmektedirler. Slav-Türk dil ilişkileri MS ilk devirlerde eski Slavca-eski Türkçe esasına dayanmaktadır. Orta çağlarda bu ilişkiler, Balkan yarımadası, Macaristan, Slovakya, Polonya, Ukrayna ve Rusya topraklarında Orta Asya ve İç Asya'ya kadar varan daha geniş bir alana yayılır. Bu alan artık Slav ve Türk halkları arasındaki oldukça sabit bir komşuluk, etnik dağılım ve devlet sınırlarıyla bazı yerlerde daralmış veya genişlemiş de olsa esas itibarıyla bugüne kadar korunmuştur. ${ }^{17}$ Anadolu'da özellikle Selçuklu ve akabinde Osmanlı Devleti; Kafkasya ve Orta Asya'da ise Altınordu ve Timur Devleti zamanından itibaren Türk-Rus ilişkileri önemli bir ivme kazanarak bazen komşuluk bazen hasımlık ilişkileri içerisinde günümüze kadar gelmiştir. Günümüzde çeşitli Türk lehçeleri konuşan halk ve milletlerin yaklaşık yarısı eski SSCB sınırları içerisinde yaşamaktadır. Bu ülkede Slav dilleri konuşan halklardan sonra sayıca ikinci sırada Türk lehçeleri konuşan halklar gelmektedir. Eski Sovyetler Birliği’nin en batı sınırlarından başlayarak Sibirya'nın en doğu yörelerine kadar Türk lehçeleri konuşulmaktadır. Eski Sovyetler Birliği dışında Türkçenin konuşulduğu yerler ise eski SSCB ile komşu olan Türkiye, İran $v b$. ile Balkan yarımadasıdır. Bu coğrafi konum Slav ve Türk halkları arasındaki ilişkilerin devam ettiğini göstermektedir. Zamanımızda da Türk lehçeleriyle öteki Slav dilleri, özellikle de Rusça arasında ilişkiler artarak devam etmekte; bu ilişkiler bazı bölge ve ülkelerde halk ağızları düzeyinde, bazı yerlerde ise yazı dilleri düzeyinde gerçekleşmektedir.

\footnotetext{
${ }^{16}$ Süleymanoğlu Yenisoy, 1998, s. 5-8.

${ }^{17}$ Süleymanoğlu Yenisoy, age., s. 5.
} 
Türkiye Türkçesine Rusçadan geçmiş olan kelimelerin büyük bir kısmı karşılıklı siyasi, sosyal ve kültürel etkileşimin doğal bir neticesi olarak karşımıza çıktığından Rusça ödünç kelimeler bugün ölçünlü dilden ziyade Anadolu ağızlarında yaşamaktadır. Türkiye'nin uzun yıllar Rusya’ya sınır komşuluğu yapan Kuzey-Doğu Anadolu Bölgesi ağızlarında, özelikle de Kars ve Erzurum ağızlarında bu gerçeği açıkça müşahede edebilmekteyiz. Türkiye Türkçesi ağızlarında yer alan Rusça alıntı kelimeler üzerine önemli bir makale yayımlamış olan Mehmet Özeren, Türkiye'de standart dilde 41 Rusça kelime bulunmasına karşın ağızlarda bu sayının 75'e çıktığını, mükerrer kullanımlarıyla beraber Anadolu ağızlarında Rusça ödünç kelime sayısının 265'i bulduğunu kaydetmiştir. ${ }^{18}$ Bu kelimelerin çoğunun Kars ve Erzurum bölgesinde yaşadığını dile getiren Özeren, bunun siyasi tarihimizle alakasına dikkat çekmiştir. Türkiye Türkçesi ağızlarındaki yabancı alıntı kelimeler üzerine yapılacak derinlemesine araştırmalar burada verilen rakamları elbette ki daha da artıracaktır.

Bizim Kars ve Erzurum ağızlarında tespit edebildiğimiz Rusça ödünç kelimeler ise aşağıda karşılıklı bir tablo hâlinde dikkatlere sunulmuştur ${ }^{19}$ :

Tablo 1: Kars ve Erzurum Ağzındaki Rusça Ödünç Kelimeler

\begin{tabular}{|c|c|c|c|}
\hline Kars Ă̆gı & Erzurum Ă̆gzı & Anlamı & Rusça Karşılığı \\
\hline- & abed & yemek, yiyecek & $\begin{array}{l}\text { obed (обед) }[\text { abet }]^{20} \\
\text { "öğle yemeği, yemek" }\end{array}$ \\
\hline- & araboke & iş, çalışma & $\begin{array}{l}\text { otrabotka (отработка) [atrabotka] } \\
\text { "çalışma" }\end{array}$ \\
\hline badval & - & bodrum, mahzen & $\begin{array}{l}\text { podval (подвал) [padval] } \\
\text { "bodrum, mahzen" }\end{array}$ \\
\hline baldon & - & kalın ve büyük palto & $\begin{array}{l}\text { balahon (балахон) [balahon] } \\
\text { "başlıklı kaban, cüppe, kapüşonlu }\end{array}$ \\
\hline
\end{tabular}

${ }^{18}$ bk. Özeren, 2014, s. 1111.

${ }^{19}$ Kelimelerin tespitinde kullandığımız kaynak malzeme aşağıdaki gibidir:

- Gemalmaz, E. (1995). Erzurum ili ağızları, (inceleme-metinler-sözlük ve dizinler). 3 Cilt, Ankara: TDK Yayınlar1.

- Ercilasun, A. B. (2002). Kars ili ăğzları (ses bilgisi). Ankara: TDK Yayınları.

- Olcay, S. vd. (1998). Arpaçay köylerinden derlemeler. Ankara: TDK Yayınları.

- Atılcan, İ. C. (1977). Erzurum ăgzl, halk deyimleri ve folklor sözlüğü. İstanbul: Erzurum Halk Oyunları, Halk Türküleri Derneği Yayınları, Kültür Matbaacılık.

- Olcay, S. (1995). Erzurum ă̆zı, (inceleme-derleme-sözlük). Ankara: TDK Yayınları.

- Ilıcalı, N. (1995). Erzurum ă̆zı. Erzurum: Ergenekon Kitap Kirtasiye Yayınları.

- Sezen, L. (2007). Erzurum folkloru. Erzurum: Atatürk Üniversitesi Yayınlar1.

- Caferoğlu, A. (1995). Doğu illerimiz ă̆ızlarından toplamalar. Ankara: TDK Yayınları.

- Türkiye'de Halk Ağzından Derleme Sözlüğü. (2009). Birleştirilmiş Tıpkıbasım, 6 Cilt, Ankara: TDK Yayınları.

- Sözlü Olarak Kendi Yaptığımız Derlemeler. Bu hususta sosyal çevremiz ve aile büyüklerimizin kültür birikiminden istifade edilmiştir.

${ }^{20}$ Kelimelerin Rusça karşılığı verilirken, sözcüğün yazılı şeklinden sonra köşeli parantez [...] içerisinde telaffuz (okuma) biçimi de verilmiştir. Bunun sebebi kelimelerin ağız bölgemize kulaktan duyma yani sözlü olarak geçmiş olması ve buna bağlı olarak Rusça ödünç kelimelerin bölge ağılarımızda Rusçada söylendiği şekliyle kullanıldığını ortaya çıkarmaktır. Kelimelerin Rusçadaki yazılış ve okunuş şekilleri Ali Bayram’ın Rusça sözlüğü esasında hazırlanmıştır. bk. Bayram, A. (2008). Rusça sözlük, "Rusça-Türkçe, Türkçe-Rusça”. İstanbul: Alfa Yay. 


\begin{tabular}{|c|c|c|c|}
\hline & & & kazak" \\
\hline- & bavusga & atlı araba & $\begin{array}{l}\text { povozka (повозка) [pavoska] } \\
\text { "atla çekilen araba" }\end{array}$ \\
\hline bedire, vedire & bedira, vedre & metal kova, bakraç & $\begin{array}{l}\text { vedro (ведро) [vedro] } \\
\text { "kova, metal kova" }\end{array}$ \\
\hline berdanga & berdinḳa & tüfek markası, silah & $\begin{array}{l}\text { berdanka (берданка) [berdanka] } \\
\text { "tüfek, bir tüfek markası" }\end{array}$ \\
\hline- & birat & kardeş, kardeşim! & $\begin{array}{l}\text { brat (брат) [brat] } \\
\text { "kardeş, erkek kardeş" }\end{array}$ \\
\hline bırişġa & - & at arabas1, fayton & $\begin{array}{l}\text { briçka (бричка) [briçka] } \\
\text { "at arabas1, atlı araba" }\end{array}$ \\
\hline- & Bolçövüg & Bolşevik (öz.is.) & $\begin{array}{l}\text { Bol'şevik (Большевик) [Bolşevik] } \\
\text { "çoğunlukçu, Bolşevik yanlısı" }\end{array}$ \\
\hline boşg்a & boşġa & yayık, fiçı, varil & $\begin{array}{l}\text { boçka (бочка) [boçka] } \\
\text { "fiçı, varil" }\end{array}$ \\
\hline çaynıh, çaynik & çaynig & çaydanlık, demlik & $\begin{array}{l}\text { çaynik (чайник) [çaynik] } \\
\text { "çaydanlık" }\end{array}$ \\
\hline- & drasde $^{*}$ & merhaba & $\begin{array}{l}\text { zdravstvuyte } \\
\text { [zdrastvuyte] } \\
\text { "merhaba" }\end{array}$ \\
\hline firğın & - & at arabas1, atlı araba, fayton & $\begin{array}{l}\text { furgon (фургон) [furgon] } \\
\text { "üstü kapalı at arabası" }\end{array}$ \\
\hline ġaloş & ḳalloş & lastik ayakkabı, şoson, galoş & $\begin{array}{l}\text { galoşi (галоши) [galoş1] } \\
\text { "galoş, kısa lastik çizme" }\end{array}$ \\
\hline $\begin{array}{l}\text { gamandar, } \\
\text { gumandar }\end{array}$ & gamandar & kumandan, komutan & $\begin{array}{l}\text { komandir (командир) [kamandir] } \\
\text { "komutan" }\end{array}$ \\
\hline gamendar & - & kaymakam, vali, komutan & $\begin{array}{ll}\text { komendant } & \text { (комендант) } \\
\text { [kamindant] } & \\
\text { "kaymakam, vali" } & \\
\end{array}$ \\
\hline - & gapısġa & lahana, lahana yemeği & $\begin{array}{l}\text { kapusta (капуста) [kapusta] } \\
\text { "lahana" }\end{array}$ \\
\hline garavat & - & karyola, yatak & $\begin{array}{l}\text { krovat’ (кровать) [kravat] } \\
\text { "yatak, karyola" }\end{array}$ \\
\hline ġazarma & ġazarma & kışla, koğuş & $\begin{array}{l}\text { kazarma (казарма) [kazarma] } \\
\text { "askerî kışla, koğuş, baraka" }\end{array}$ \\
\hline - & gazonni & resmî, kamusal & $\begin{array}{l}\text { kazyonnıy (казённый) [kazyonnıy] } \\
\text { "devlet, devlete ait, resmî" }\end{array}$ \\
\hline genfet & - & bayram şekeri, çikolata & $\begin{array}{l}\text { konfeta (конфета) [kanfeta] } \\
\text { "şeker, bonbon" }\end{array}$ \\
\hline gepiyh & ḳapig & değersiz para, kuruş & $\begin{array}{l}\text { kopeyka (копейка) [kapiyka] } \\
\text { "para, kuruş para, kapik" }\end{array}$ \\
\hline ġırşa & - & çat1, dam & $\begin{array}{l}\text { krışa (крыша) [krişa] } \\
\text { "çatı, dam, çatı katı" }\end{array}$ \\
\hline gociyh & gocik & kisa palto, kaban & $\begin{array}{l}\text { kojuh (кожух) [kojuh] } \\
\text { "palto, kaban" }\end{array}$ \\
\hline gopça & ḳopça & düğme, çengel, kanca & $\begin{array}{l}\text { knopka (кнопка) [knopka] } \\
\text { "düğme, raptiye" }\end{array}$ \\
\hline - & guburnat & vali, kaymakam & $\begin{array}{l}\text { gubernator } \\
\text { [gubirnatır] } \\
\text { "vali" }\end{array}$ \\
\hline gunut & - & uzun kamçı, kırbaç & $\begin{array}{l}\text { knut, (кнут) [knut] } \\
\text { "kırbaç, kamçı" }\end{array}$ \\
\hline ġuşġa, kuş̧̇ga & - & taş veya toprak yığını & $\begin{array}{l}\text { kuçka (кучка) [kuçka] } \\
\text { "grup, yığın, demet, kum yığını" }\end{array}$ \\
\hline isdol & isdol & sehpa, masa, sandalye & stol (стол) [stol] \\
\hline
\end{tabular}

* Yıldı $\left({ }^{*}\right)$ işareti ile gösterilen kelimeler, bölge ağızlarında kullanılmaz; ancak derleme metinlerinde geçtiği için buraya alınmıştır. 


\begin{tabular}{|c|c|c|c|}
\hline & & & "masa, sehpa" \\
\hline istiḳan, isteḳan & istiḳan & bardak, çay bardağ 1 & $\begin{array}{l}\text { stakan (стакан) [stakan] } \\
\text { "bardak, cam bardak" }\end{array}$ \\
\hline işgaf & - & dolap & $\begin{array}{l}\text { şkaf (шкаф) [şkaf] } \\
\text { "dolap" }\end{array}$ \\
\hline- & iştoy* $^{*}$ & ne, nasıl, niçin, hangi & $\begin{array}{l}\text { çto (что) [şto] } \\
\text { "ne, hangi, nasil, niçin; bu" }\end{array}$ \\
\hline izbe & izbe & 1ss1z yer, 1ss1z kulübe & $\begin{array}{l}\text { izba (изба) [izba] } \\
\text { "köylü kulübesi, ahşap ev" }\end{array}$ \\
\hline kartol, kartof & kartol, kartul, kartof & patates & $\begin{array}{l}\text { kartofel’ (картофель) [kartofil] } \\
\text { "patates" }\end{array}$ \\
\hline- & ḳatilig & sefer tası, tahıl ölçeği & $\begin{array}{l}\text { kotelok (котелок) [katilok] } \\
\text { "sefer tas1, tencere; melon şapka" }\end{array}$ \\
\hline- & kuda* & nereye, nerede? & $\begin{array}{l}\text { kuda (куда) [kuda] } \\
\text { "nereye" }\end{array}$ \\
\hline lapatga & - & büyük kürek & $\begin{array}{l}\text { lopatka (лопатка) [lapatka] } \\
\text { "kürek" }\end{array}$ \\
\hline- & Lenen & Lenin (öz.is.) & $\begin{array}{l}\text { Lenin (Ленин) [Lenin] } \\
\text { "Lenin (öz.is.)" }\end{array}$ \\
\hline lobya & lobiya & taze fasulye, fasulye & $\begin{array}{l}\text { lobiya (лобия) [lobiya] } \\
\text { "fasulye" }\end{array}$ \\
\hline loda & loda & yığın, küme, birikinti & $\begin{array}{l}\text { gruda (груда) [gruda] } \\
\text { "y1ğın, küme, taş yığını" }\end{array}$ \\
\hline lom & lom & kaldıraç, levye & $\begin{array}{l}\text { lom (лом) [lom] } \\
\text { "demir levye, kaldıraç" }\end{array}$ \\
\hline- & maladoy $^{*}$ & çocuk, genç & $\begin{array}{l}\text { molodoy (молодой) [maladoy] } \\
\text { "çocuk, genç; yeni" }\end{array}$ \\
\hline Malakan & Malakan & Malakan (öz.is.) & $\begin{array}{l}\text { Molokane (Молокане) [Malakani] } \\
\text { "Malakan (öz.is.)" }\end{array}$ \\
\hline- & malinkiy* $^{*}$ & küçük, ufak, minik & $\begin{array}{l}\text { malen'kiy (маленький) [malinkiy] } \\
\text { "küçük, ufak; çocuk” }\end{array}$ \\
\hline Manat & Manat & Manat, Rus parası (öz.is.) & $\begin{array}{l}\text { Moneta (Монета) [Maneta] } \\
\text { "madeni para, Manat" }\end{array}$ \\
\hline Mosg்iva & Mosg்iva & Moskova (öz.is.) & $\begin{array}{l}\text { Moskva (Москва) [Maskva] } \\
\text { "Moskova (öz.is.)" }\end{array}$ \\
\hline- & mujik & erkek asker, er, köylü & $\begin{array}{l}\text { mujik (мужик) [mujik] } \\
\text { “erkek, adam, er, asker, köylü”, }\end{array}$ \\
\hline müşdüyh & - & ağızlık, zıvana & $\begin{array}{l}\text { mundştuk (мундштук) [munştuk] } \\
\text { "ağızlık, sigara ağızlığı" }\end{array}$ \\
\hline- & müsürlük & hayvan yemliği & $\begin{array}{l}\text { musor+(lUk) (мycop) [musır] } \\
\text { "çöp, çöp kutusu, çöplük" }\end{array}$ \\
\hline- & neçova* & hiçbir şey, bir şey yok & $\begin{array}{l}\text { niçego (ничего) [neçiva] } \\
\text { "bir şey yok, gereği yok, sorun } \\
\text { değil, hiçbir şey" }\end{array}$ \\
\hline Niġalay & Nigalay & Nikola, Nikolay (öz.is.) & $\begin{array}{l}\text { Nikolay (Николай) [Nikalay] } \\
\text { "Nikolay (öz.is.)" }\end{array}$ \\
\hline peçet & - & mühür & $\begin{array}{l}\text { peçat' (печать) [piçet] } \\
\text { “mühür, bask1, basın” }\end{array}$ \\
\hline pej, pec & pej & soba, şömine & $\begin{array}{l}\text { реç' (печь) [peç] } \\
\text { "ssoba, ocak, firın, şömine", }\end{array}$ \\
\hline- & Petrosgrad & Petrograd, Petersburg (öz.is.) & $\begin{array}{l}\text { Petrograd (Петроград) [Petrograd] } \\
\text { "Petrograd (öz.is.)" }\end{array}$ \\
\hline- & poḳkazarma & kışla, askerî bina & $\begin{array}{l}\text { pod kazarma (под казарма) [pod } \\
\text { kazarma] } \\
\text { "k1şla, koğuş, askerî bina”" }\end{array}$ \\
\hline put & put & $\begin{array}{l}\text { ağırlık ölçüsü, batman, üç } \\
\text { tenekelik tahıl ölçüsü }\end{array}$ & $\begin{array}{l}\text { pud (пуд) [pud] } \\
\text { "16 kilogramlık ağırlık ölçüsü, tahıl } \\
\text { ölçeği”" }\end{array}$ \\
\hline
\end{tabular}




\begin{tabular}{|c|c|c|c|}
\hline putḳa & - & karayolları bakımevi & $\begin{array}{l}\text { budka (будка) [butka] } \\
\text { "kulübe" }\end{array}$ \\
\hline - & raposki!* & dağıtma, dağılın, çalışıı! & $\begin{array}{l}\text { rospusk (роспуск) [rospusk] } \\
\text { "dağıtma, dağıtılma" }\end{array}$ \\
\hline saldat & saldat & asker, er & $\begin{array}{l}\text { soldat (солдат) [saldat] } \\
\text { "asker, er" }\end{array}$ \\
\hline - & samavar & semaver & $\begin{array}{l}\text { samovar (самовар) [samavar] } \\
\text { "semaver, büyük çaydanlık" }\end{array}$ \\
\hline- & $\begin{array}{l}\text { seggevül, seggevil, } \\
\text { saġgavul }\end{array}$ & çalı süpürgesi, çalı & $\begin{array}{l}\text { saksaul (саксаул) [saksaul] } \\
\text { "saksavul ağac1, çalılık, çalı } \\
\text { süpürgesi, çalı" }\end{array}$ \\
\hline sımışḳa, simişḳa & sımış̧a, sımışġa & ay çiçeği çekirdeği, ay çiçeği & $\begin{array}{l}\text { semiçko (семечко) [semiçka] } \\
\text { "ay çiçeği çekirdeği, ay çiçeği, } \\
\text { tohum" }\end{array}$ \\
\hline şapġa, şafg̉a & şapg்a & şapka, başl1k & $\begin{array}{l}\text { şapka (шапка) [şapka] } \\
\text { "şapka, başlık, bere" }\end{array}$ \\
\hline şinel & - & palto, kaban & $\begin{array}{l}\text { şinel' (шинель) [şınel] } \\
\text { "palto" }\end{array}$ \\
\hline Urus & Urus & Rus, Rusyalı (öz.is.) & $\begin{array}{l}\text { Russkiy (Русский) [Ruskiy] } \\
\text { "Rus (erkek)" }\end{array}$ \\
\hline Urusya & Urusiya & Rusya (öz.is.) & $\begin{array}{ll}\text { Rossiyskiy } & \text { (Российский) } \\
\text { [Rasiskiy] } & \\
\text { "Rusya (öz.is.)" } & \\
\end{array}$ \\
\hline - & vaporöz & sigara, ağızlıklı sigara & $\begin{array}{l}\text { papirosa (папироса) [papirosa] } \\
\text { "sigara" }\end{array}$ \\
\hline - & voda $^{*}$ & su, içecek & $\begin{array}{l}\text { voda (вода) [vada] } \\
\text { "su" }\end{array}$ \\
\hline- & volespet & bisiklet & $\begin{array}{l}\text { velosiped (велосипед) [vilasiped] } \\
\text { "bisiklet" }\end{array}$ \\
\hline - & $\mathrm{ya}^{*}$ & ben, kendim & $\begin{array}{l}\text { ya (я) [ya] } \\
\text { "ben, I. tekil kişi zamiri" }\end{array}$ \\
\hline - & yabluk $^{*}$ & elma & $\begin{array}{l}\text { yabloko (яблоко) [yablaka] } \\
\text { "elma" }\end{array}$ \\
\hline - & yura $^{*}$ & nara, haykırma, alkış & $\begin{array}{l}\text { ura! (ypa) [ura] } \\
\text { "nara, alkış, yaşasın!" }\end{array}$ \\
\hline - & zaġon & kanun, hukuk, ahlak, irade & $\begin{array}{l}\text { zakon (закон) [zakon] } \\
\text { "kanun, yasa, hukuk" }\end{array}$ \\
\hline zanḳa & zanḳa & kızak, atlı kızak, fayton & $\begin{array}{l}\text { sanka (санка) [sanka] } \\
\text { "kızak, atlı kızak" }\end{array}$ \\
\hline - & zapusga & izin belgesi, ruhsat & $\begin{array}{l}\text { zapiska (записка) [zapiska] } \\
\text { "belge, hatırlatma notu" }\end{array}$ \\
\hline zavot & zavot & mandıra, çiftlik, süt ineği & $\begin{array}{l}\text { zavod (завод) [zavot] } \\
\text { "fabrika, imalathane" }\end{array}$ \\
\hline - & zlğva & $\begin{array}{l}\text { şalvar, pantolon, zıpka, ağ1 } \\
\text { körüklü dar paçalı potur }\end{array}$ & $\begin{array}{l}\text { zipka (зипка) [zipka] } \\
\text { "şalvar, ağı körüklü dar paçalı } \\
\text { geleneksel potur" }\end{array}$ \\
\hline
\end{tabular}

Tablo 2: Kars ve Erzurum Ağzında Tespit Edilen Rusça Ödünç Kelimelerin Sayısal Değerleri

\begin{tabular}{l}
\hline Tespit Edilen Toplam Kelime Sayısı: 78 \\
\hline Özel Kullanıma Ait Kelimeler: 11 (Sadece Erzurum ağzında tespit edildi) \\
\hline Özel İsim olanlar: 9 \\
\hline Kars Ağzında Tespit Edilen Toplam Kelime Sayısı: 46 \\
\hline Erzurum Ağzında Tespit Edilen Toplam Kelime Sayısı: 62 \\
\hline Sadece Kars Ağzında Bulunan Kelimeler: 16 \\
\hline Sadece Erzurum Ağzında Bulunan Kelimeler: 33 \\
\hline Her İkisinde de Ortak Bulunan Kelimeler: 29 \\
\hline
\end{tabular}


Yukarıdaki tablolardan anlaşılacağı üzere Kars ve Erzurum ağızlarında toplam 78 Rusça ödünç sözcük tespit edilmiştir. Bu kelimelerin bir kısmı her iki ağız bölgesinde de görülürken bazıları sadece Kars veya sadece Erzurum ağzına münhasır kelimelerdir. Ayrıca bu 78 Rusça ödünç sözcükten 11 tanesi derleme metinlerinde geçtiği hâlde bölge ağızlarında kullanılmamaktadır: “drasde, iştoy, kuda, maladoy, malinkiy, neçova, raposki, voda, ya, yabluk, yura". Bu 11 kelime, genelde derleme yapılan kişinin Ruslarla ilgili hatıralarını anlatırken kullandığı Rusça ifadeler arasında geçmektedir. Yani bu kelimeler aslında yöre halkına değil, derleme yapılan kişinin kelime hafızasına dayanmaktadır. Yine yukarıdaki tabloda geçen 9 kelime özel isim (şahıs ismi, yer ismi vb.) niteliğindedir: "Bolçövüyh, Lenen, Malakan, Manat, Mosgiva, Nigalay, Petrosgred, Urus, Urusiya”. Özel isimlerle beraber, derlenen kişilere has kelimelerin sayısı 20'yi bulmaktadır. Özel işleve sahip bu 20 kelimeyi liste dışında tutsak bile bugün Kars ve Erzurum ağızlarında toplam 58 Rusça ödünç kelime ile karşılaşmış oluyoruz ki bu hiç de azımsanacak bir rakam değildir.

Tespit edilen söz konusu kelimelerin standart dilden ziyade bölge ağızlarımızda yaşıyor olması kanaatimizce Türkçe-Rusça dil ilişkilerinin ileri bir merhaleye ulaştığını kanıtlamaktadır. Kelimelerin içeriğine baktığımızda bunların önemli bir kısmının günlük hayatta özellikle de köy hayatında kullanılan birtakım alet edevat isimleri olduğunu görüyoruz. Kelimelerin yine önemli bir kısmı askerî terimler olarak karşımıza çıkıyor. Bu durum, meselenin siyasi ve sosyal yönünü de göz önüne seriyor. Ancak burada verilen kelimelerin artık pek çoğunun unutulmaya başlandığını, diğer yöresel kelimelerimizde olduğu gibi bu kelimelerin de genç nesil tarafından pek bilinmediğini belirtmek isteriz.

Son olarak yukarıda tespit edilen kelimelerin dışında Kars ve Erzurum ağzına, Rusça kanalıyla girmiş başka yabancı asıllı kelimelerin bulunduğunu da söyleyelim. Fakat böyle bir çalışma daha farklı ve geniş bir araştırmayı gerektireceği için bu konuyu şimdilik inceleme alanımız dışında tuttuk.

\section{Rusça Ödünç Kelimelerde Meydana Gelen Ses Olayları}

Bilindiği üzere dilde kelimeler zaman içerisinde kullanıla kullanıla birtakım seslerini düşürür, bazı yeni sesler türetir, bazı seslerini değiştirir veya seslerini birbirine benzetir. İşte dilde sese dayalı bu gelişimlerin hepsine ses olayları adı verilir. Bu ses olaylarının büyük bir kısmı en az çaba yasasından (ekonomi kanunu) kaynaklanır. Çünkü daha az enerji ile daha çok şey ifade etme veya kelimeleri, cümleleri daha az enerji ile daha kolay bir şekilde söyleyebilme 
bütün dillerin ortak arzusudur. ${ }^{21}$ Türkçenin tarihî gelişim süreci içerisinde meydana gelen ses olaylarına baktığımızda daha çok patlayıcı seslerin sızıcılaştığını, katı seslerin akııılaştığını, sert seslerin yumuşadığını hatta bu yumuşayan, sızıcılaşan, akıcılaşan seslerin gittikçe ünlüye yaklaşarak üzerlerindeki bilgi yükünü azaltıp zamanla düştüğünü görürüz. Ünlülerde ise genelde yuvarlaktan düze, genişten dara doğru, yani daha fazla enerji gerektiren ünlüden daha az enerji gerektiren ünlüye doğru, bir değişim söz konusudur. Hatta birçok ünlü, daralmanın veya düzleşmenin ötesinde zamanla aşınıp düşmektedir. ${ }^{22}$ Kelimelerdeki bu ses gelişimi aslında insanoğlunun dilinin günbegün daha olgunlaştığını ortaya koyar. Dolayısıyla tarihî dil incelemeleri dillerin gelişim ve olgunlaşma evrelerini gözler önüne sererek günümüzdeki dilsel birçok sorunun çözülmesine imkân sağlar.

Türkçeye yabancı dillerden giren ödünç kelimelerin zamanla Türkçenin ses kurallarına uydurularak Türkçeleştirildiği bilinen bir gerçektir. Özellikle ses benzeşmelerinin (ünlü uyumları, ünsüz uyumları, ünlü-ünsüz uyumları) bu bağlamda rolü yadsınamaz. Bunun yanı sıra alıntı kelimelerin başında, sonunda veya ortasında sıklıkla rastladığımız ünlü veya ünsüz yığılmalarını kabullenemeyen dilimizin bu sorunu gidermede pek çok ses olayını devreye soktuğunu belirtelim.

Araştırma bölgemiz olan Kars ve Erzurum ağızlarında tespit edilen Rusça asıllı ödünç kelimelerde meydana gelen ses olayları da genelde dil içi sebeplerle ve dilin doğal gelişimine uygun olarak karşımıza çıkmaktadır. Bu bağlamda Rusça ödünç kelimelerin pek çoğu, Kars ve Erzurum ağızlarında önemli ses olaylarına maruz kalarak Türkçeleşmiştir diyebiliriz.

Yöremiz ağızlarındaki alıntı Rusça kelimelerde meydana gelen ses olaylarını üç ana başlık altında toplamak mümkündür: ses düşmesi, ses türemesi ve ses değişmesi. Aşağıda bu ses olayları örnekleriyle beraber dikkatlere sunulmuştur:

\footnotetext{
${ }^{21}$ Dildeki ekonomi kanununa göre; "Mümkün olduğu kadar az enerji ve madde sarfiyla, birim zamanda, mümkün olduğu kadar çok ve eksiksiz mesaj kodlayıp iletme bütün doğal ve yapay dillerin eğilimidir.” bk. Gemalmaz, 1982, s. 28.

${ }^{22}$ Prof. Dr. Efrasiyap GEMALMAZ, Türkçedeki seslerin açıklık derecelerini (aperture) bir tablo üzerinde göstererek eskiden günümüze Türkçede meydana gelen ses olaylarını yirmi bir maddeyle izah etmiştir. Gemalmaz, E. (1999). Türkiye Türkçesindeses olayları. Atatürk Üniversitesi Türkiyat Araştırmaları Enstitüsü Dergisi, 13, 1-27.
} 


\section{Ses Düşmesi}

\section{1. Ünlü Düşmesi}

\subsubsection{Kelime İçi Ünlü Düşmesi}

(балахон) [balahon] > baldon: -a- > -ø-

(крыша) [ḳrişa] > ġışa: -i- > -ø-

(картофель) [kartofil] > ḳartol: -i- > -ø-

(лобия) [lobiya] > lobya: -i- > -ø-

\subsubsection{Kelime Sonu Ünlü Düşmesi}

(галоши) [ galoşı] > ḳalloş: $-1>-\varnothing$

(конфета) [kanfeta] > genfet: $-\mathrm{a}>-\varnothing$

(копейка) [ḳapiyḳa] > ḳapig: -a > -ø

(Молокане) [Malaḳani] > Malaḳan: -i > -ø

(Монета) [Maneta] > Manat: -a > -ø

(папироса) [papirosa] > vaporöz: $-\mathrm{a}>-\varnothing$

(яблоко) [yablaḳa] > yabluk: -a > -ø

\section{2. Ünsüz Düşmesi}

\subsubsection{Kelime Başı Ünsüz Düşmesi}

(здравствуйте) [zdrastvuyte] > drasde: z- $>\varnothing-$

(груда) [g்ruda] > loda: $\dot{\mathrm{g}}->\varnothing-$

\subsubsection{Kelime İçi Ünsüz Düşmesi}

(отработка) [atrabotka] > araboke: -t- > -ø-

(здравствуйте) [zdrastvuyte] > drasde: -t- > -ø-

(копейка) [ḳapiyḳa] > ḳapig: -y- > -ø-

(картофель) [kartofil] > ḳartol: -f- > -ø-

(кнопка) [ḳnopḳa] > ḳopça: -n- > -ø-

(мундштук) [munştuk] > müşdüyh: -n- > -ø-

(роспуск) [rospusk] > raposki: -s- > -ø-

(саксаул) [sakssaul] > segevül: -s- > -ø-

\subsubsection{Kelime Sonu Ünsüz Düşmesi}

(казённый) [kazyonnıy] > gazonni: -y > -ø

\section{Ses Türemesi}

\section{1. Ünlü Türemesi}

\subsubsection{Kelime Başı Ünlü Türemesi}

(стол) [stol] > isdol: ø- > i-

(стакан) [staḳan] > istiḳan: ø- > i- 
(шкаф) [şkaf] > işgaf: ø- > i-

(что) [şto] > iştoy: ø- > i-

(Русский) [Ruskiy] > Urus: ø- > u-

\subsubsection{Kelime İçi Ünlü Türemesi}

(ведро) [vedro] > bedira: -ø- > -i-

(брат) [brat] > birat: - $\varnothing->-1-$

(бричка) [briçķa] > bırişgáa: -ø- > -1-

(кровать) [kravat] > garavat: -ø- > -a-

(крыша) [k़rişa] > ġırşa: -ø- > -1-

(кнут) [ḳnut] > gंunut: -ø- > -u-

(Москва) [Masḳva] > Mosgiva: ; - - > -1-

\subsubsection{Kelime Sonu Ünlü Türemesi}

(роспуск) [rospusk] > raposki: - $>$ > -i

\section{2. Ünsüz Türemesi}

\subsubsection{Kelime Başı Ünsüz Türemesi}

(ypa) [ura] > yura: ø- > y-

\subsubsection{Kelime İçi Ünsüz Türemesi}

(галоши) [g்aloșı] > ḳalloş: -ø- > -1-

(Петроград) [Petrograd] > Petrosgrad: -ø- >-s-

(саксаул) [saḳsaul] > seggevül: -ø- > -v-; -ø- > g

\subsubsection{Kelime Sonu Ünsüz Türemesi}

(что) [şto] > iştoy: -ø > -y

\section{Ses Değiş̧mesi}

\section{1. Ünlü Değişmeleri}

\subsection{1. Ünlü Kalınlaşması}

(Монета) [Maneta] > Manat: -e- > -a-

(семечко) [semiçka] > sımışka: -e- > -1-; -i- > -1-

(папироса) [papirosa] > vaporöz: -i- > -o-

(зипка) [zipḳa] > zığva: -i- > -1-

(записка) [zapisḳa] > zapusgia: -i- > -u-

\subsection{2. Ünlü İncelmesi}

(отработка) [atrabotka] > araboke: -a >-e

(казённый) [kazyonnıy] > gazonni: -1 > -i

(конфета) [k़anfeta] > genfet: -a- > -e-

(кожух) [kojuh] > gocik: -u- > -i- 
(стакан) [staḳan] > istiḳan: -a- > -i-

(изба) [izba] > izbe: -a >-e

(саксаул) [saḳsaul] > seggevül: -a- > -e-; -u- < -ü-

(шинель) [şınel] > şinel: -1- > -i-

(папироса) [papirosa] > vaporöz: -o- > -ӧ-

\subsection{3. Ünlü Düzleşmesi}

(ведро) [vedro] > bedira: -o > -a

(фургон) [furgon] $>$ firğın: -u- $>-1-,-$-o- $>-1-$

(капуста) [kapusta] > gapısga: -u- > -1-

(котелок) [katiloḳ] > ḳatilig: -o- > -i-

(роспуск) [rospusk] > raposki: -o- > -a-

\subsection{4. Ünlü Yuvarlaklaşması}

(Большевик) [Bolşevik] > Bolçövüg: -e- > -ö-, -i- > -ü-

(губернатор) [g்ubirnatır] > guburnat: -i- > -u-

(мyсор) [musır] > müsür+lük: -i- > -ü-

(ничего) [neçiva] > neçova: -i- > -o-

(вода) [vada] > voda: -a- > -о-

(велосипед) [vilasiped] > volespet: -i- > -o-

(записка) [zapisḳa] > zapusgia: -i- > -u-

(яблоко) [yablaḳa] > yabluḳ: -a- > -u-

\subsection{5. Ünlü Genişlemesi}

(командир) [kamandir] > gamandar: -i- > -a-

(Ленин) [Lenin] > Lenen: -i- > -e-

(груда) [g̈ruda] > loda: -u- > -o-

(печать) [piçet] > peçet: -i- > -e-

(папироса) [papirosa] > vaporöz: -i- > -o-

\subsection{6. Ünlü Daralması}

(повозка) [pavosḳa] > bavusgaa: -o- > -u-

(стакан) [staḳan] > istiḳan: -a- > -i-

(яблоко) [yablaḳa] > yabluk: -a- > -u-

\section{2. Ünsüz Değişmeleri}

\subsubsection{Tonlulaşma}

(подвал) [padval] > badval: p- > b-

(балахон) [balahon] > baldon: -h- - >-d-

(повозка) [pavosḳa] > bavusgia: p- > b-; -ḳ- > - $\dot{\text { g- }}$ 
(берданка) [berdanḳa] > berdanġa: -k- > - $\dot{\mathrm{g}}$ -

(бричка) [briçḳa] > bırişgàa: -ḳ- > - $\dot{\mathrm{g}}-$

(Большевик) [Bolşevik] > Bolçövüg: -k > -g

(бочка) [boçķa] > boşgà: -ḳ- > - -

(чайник) [çaynik] > çaynig: -k > -g

(здравствуйте) [zdrastvuyte] > drasde: -t- > -d-

(командир) [kamandir] > gamandar: k- > $\dot{\mathrm{g}}-$

(капуста) [kapusta] > gapısga: k $\mathrm{k}->$ g-

(кровать) [kravat] > garavat: $\mathrm{k}->\dot{\mathrm{g}}-$

(казарма) [kazarma] > gazarma: k- > $\dot{\text { g- }}$

(казённый) [kazyonnıy] > gazonni: k- > g-

(конфета) [kanfeta] > genfet: k- $<$ g-

(копейка) [kapiyḳa] > kapig: k- > g-

(крыша) [krrişa] > ġırşa: k- > g-

(кожух) [kojuh] > gocik: k- > g-

(кнут) [knut] > ginut: k- > g-

(кучка) [kuçķa] > guş̧ga: ḳ- > g-, -k- > - $\dot{\mathrm{g}}-$

(стол) [stol] > isdol: -t- > -d-

(шкаф) [şḳaf] > işġaf: -ḳ- > - $\dot{\mathrm{g}}-$

(котелок) [katiloḳ] > katilig: -k > -g

(лопатка) [lapatḳa] > lapatġa: -ḳ- > -g-

(Москва) [Masḳva] > Mosǵıva: -ḳ- > -g-

(мундштук) [munştuk] > müşdüyh: -t- > -d-

(Николай) [Nikalay] > Nigalay: -k- > -g-

(саксаул) [sakssaul] > seggevül: -ḳ- > -g-

(шапка) [şapḳa] > şapgia: -ḳ- > - $\dot{\text { g }}$

(папироса) [papirosa] > vaporöz: ; -s > -z

(закон) [zaḳon] > zagion: -ḳ- > - $\dot{\text { g- }}$

(санка) [sanka] > zanka: s- > z-

(записка) [zapisḳa] > zapusgia: -ḳ- > - $\dot{\mathrm{g}}$ -

(зипка) [zipḳa] > zıg̀va: -ḳ- > - -

\subsubsection{Tonsuzlașma}

(будка) [butka] > putka: b- > p-

(пуд) [pud] > put: -d > -t

(велосипед) [vilasiped] > volespet: $-\mathrm{d}>-\mathrm{t}$ 


\subsubsection{Sızıcılaşma}

(бричка) [briçķa] > bırişġa: -ç- > -ş-

(бочка) [boçḳa] > boşġa: -ç- > -ş-

(фургон) [furgion] > firğın: - $\dot{\mathrm{g}}->-\breve{\mathrm{g}}-$

(кучка) [ḳuçḳa] > ġuşgaa: -ç- > -ş-

(мундштук) [munştuḳ] > müşdüyh: -ḳ > -ỵh

(печь) [рес̧] > pej: $-c ̧>-j$

(папироса) [papirosa] > vaporöz: p- > v-

(зипка) [zipḳa] > zıvğa: -p- > -v-

\subsubsection{Patlayıcılaşma}

(балахон) [balahon] > baldon: -h- > -d-

(ведро) [vedro] > bedira: v- > b-

(Большевик) [Bolşevik] > Bolçövüg: -ş- > -ç-

(кожух) [kojuh] > gocik: -j- <-c-

Tablo 3: Tespit Edilen Ses Olaylarının Sayısal Dökümü ${ }^{23}$

\begin{tabular}{|c|c|c|c|c|c|}
\hline \multicolumn{2}{|c|}{ ANA SES OLAYI } & "AYRINTI SES OLAYI & SAYI; ORAN & \multicolumn{2}{|c|}{ TOPLAM; ORAN } \\
\hline \multirow{2}{*}{\multicolumn{2}{|c|}{ Ses Düşmesi }} & Ünlü Düşmesi & $11 ; \% 9$ & \multirow{2}{*}{\multicolumn{2}{|c|}{$22 ; \% 17$}} \\
\hline & & "̈̈nsüz Düşmesi & $11 ; \% 9$ & & \\
\hline \multirow{2}{*}{\multicolumn{2}{|c|}{ Ses Türemesi }} & Ü̈nlü Türemesi & $13 ; \% 10$ & \multirow{2}{*}{\multicolumn{2}{|c|}{$19 ; \% 15$}} \\
\hline & & Ü̈nsüz Türemesi & $6 ; \% 5$ & & \\
\hline \multirow[t]{10}{*}{ Ses Değişmesi } & \multirow[t]{6}{*}{ Ünlü } & Ü̈nlü İncelmesi & $10 ; \% 8$ & \multirow{6}{*}{$39 ; \% 30$} & \multirow{10}{*}{$90 ; \% 69$} \\
\hline & & Ünlü Yuvarlaklaşması & $9 ; \% 7$ & & \\
\hline & & " Ünlü Kalınlaşması & $6 ; \% 5$ & & \\
\hline & & "̈̈̈nlü Düzleşmesi & $6 ; \% 5$ & & \\
\hline & & "Ünlü Genişlemesi & $5 ; \% 4$ & & \\
\hline & & Ü̈nlü Daralması & $3 ; \% 2$ & & \\
\hline & \multirow[t]{4}{*}{ Ünsüz } & "Tonlulaşma & $36 ; \% 28$ & \multirow{4}{*}{$51 ; \% 39$} & \\
\hline & & "Sızıcılaşma/Akıcılaşma & $8 ; \% 6$ & & \\
\hline & & "Patlayıcılaşma & $4 ; \% 3$ & & \\
\hline & & "Tonsuzlaşma & $3 ; \% 2$ & & \\
\hline
\end{tabular}

\footnotetext{
${ }^{23}$ Yüzdelik oranlar verilirken (0.5)'lik dilimi geçenler bir üst sayıya yuvarlanmıştır.
} 


\section{Sonuç}

Türk-Slav ilişkileri yaklaşık 1500 yıllık bir tarihî derinliğe sahiptir. Bu engin tarihî zemin içerisinde Türklerle Ruslar devamlı surette birbirleriyle -bazen dostane bazen hasmanekomşuluk ilişkisi içinde bulunmuşlardır. Bu durum iki ulusun ticari, askerî, siyasi, sosyal ve kültürel etkileşim içerisinde olmalarını zorunlu kılmıştır. Bunun neticesinde Türkçe ile Rusça birbirini sürekli etkileyen iki köklü dil olarak karşımıza çıkmıştır. Bugün her iki dilin tüm lehçe ve ağızlarıyla beraber birbirlerinden alıp verdikleri kelime sayısı binlerle ölçülmektedir. Standart Türkiye Türkçesinde Rusça asıllı 39 sözcük bulunmasına karşın ağızlarda bu sayı 100'e yaklaşmaktadır. Yine diğer Türk lehçelerini işin içine kattığımızda bu sayı 1000'leri aşmaktadır. Türk dili ve lehçelerinden Rusçaya geçmiş kelime sayısı ise 2500 civarındadır. Türkiye'de halk ağzından yapılan derleme sözlüklerini ve ağız araştırmalarını incelediğimizde günümüzde Türkiye Türkçesi ağızlarında yer alan Rusça ödünç kelimelerin önemli bir kısmının Doğu Anadolu ağızlarında ve daha ziyade Kars, Erzurum ağızlarında bulunduğu görülmektedir. $\mathrm{Bu}$ durum, iki şehrin coğrafi ve jeopolitik konumlarının yanı sıra Rusya ile olan yakın tarihî ilişsilerinin neticesidir.

Tarihî dönemlerde diller arası ilişkiler dolaylı yollarla veya doğrudan gerçekleşmiştir. Komşuluk ilişkisi olmayan diller arasındaki etkileşimlerde, daha çok aracı diller söz konusu olduğu için dolaylı ve suni bir ilişki oluşmuştur. Coğrafi yakınlığın da getirmiş olduğu bir sonuç olarak sosyal, siyasi ve askerî ilişkiler içerisinde bulunmuş olan komşu diller arasında ise doğrudan dil ilişkileri meydana gelmiştir. ${ }^{24}$ Türkiye Türkçesine Rusçadan geçen kelimelerin bugün standart dili aşarak ağızlara sirayet etmesi ve halkın dilinde yaşayabilmesi doğal dil etkileşimini en güzel şekilde gözler önüne sermektedir. Yeryüzündeki tüm diller geçmişte olduğu gibi bundan sonra da birbirlerini etkilemeye devam edecektir. Rusça-Türkçe ilişkilerinin de hızlanan küreselleşmenin ve artan iletişim imkânlarının doğal bir sonucu olarak bu genel kaideden nasibini alacağına şüphe yoktur.

\section{Kaynaklar}

Aksan, D. (2003). Her yönüyle dil: Ana çizgileriyle dilbilim. 3 Cilt. Ankara: TDK Yayınları.

Atılcan, İ. C. (1977). Erzurum ağzl, halk deyimleri ve folklor sözlüğ̈̈. İstanbul: Erzurum Halk Oyunları, Halk Türküleri Derneği Yayınları, Kültür Matbaacılık.

\footnotetext{
${ }^{24}$ Özeren, M. (2014). Türkiye Türkçesi ağızlarındaki Rusça sözcükler. Turkish Studies - International Periodical For The Languages, Literature and History of Turkish or Turkic, 9/3, 1093-1120.
} 
$176^{*}$ TAED 55

Muharrem DAŞDEMIR - Süleyman EFENDiOĞLu

Ayverdi, İ. (2008). Misalli büyük Türkçe sözlük. 3 Cilt, İstanbul: Kubbealtı Neşriyatı Yayınları.

Bayram, A. (2008). Rusça sözlük (Rusça-Türkçe, Türkçe-Rusça). İstanbul: Alfa Yayınları.

Bazin, L. (1992). Türk lengüistiği ve kültür alışverişi meseleleri: Ön rapor (çev. Gemalmaz, E.). Fen-Edebiyat Fakültesi Edebiyat Bilimleri Araştırma Dergisi, S.19'dan ayrı basım, Erzurum.

Buran, A. (1992). Doğu ve Güneydoğu Anadolu üzerine araşttrmalar II (Ăğzlar). Ankara: Boğaziçi Yayınları.

Caferoğlu, A. (1994). Anadolu ă̆ızlarından toplamalar. Ankara: TDK Yayınları.

Caferoğlu, A. (1995). Anadolu illeri ağızlarından derlemeler. Ankara: TDK Yayınları.

Caferoğlu, A. (1995). Doğu illerimiz ă̆ızlarından toplamalar. Ankara: TDK Yayınları.

Clauson, S. G. (1972). An etymological dictionary of pre-thirteenth - centruy Turkish. London: Oxford University Prees.

Çağbayır, Y. (2007). Ötüken Türkçe sözlük. 5 Cilt. İstanbul: Ötüken Neşriyat.

Dankoff, R. (1995). Armenian loanwords in Turkish (Turcologica 21). Wiesbaden: Harrassowitz.

Daşdemir, M. (2002). Türkiye'de Türk-Gürcü dil etkileşimi. Akhalstsikhe-Kars Sempozyumu, 23-24 May1s 2002, Abastumani, Gürcistan.

Daşdemir, M. (2014). Türkçede ekonomi yasasına aykırı fonetik değişiklikler. Türk Dil Bilgisi Toplantılart-II: Türkiye Türkçesi Ses ve Şekil Bilgisi Sempozyumu (Türk Dil KurumuSelçuk Üniversitesi), 31 Ekim-1 Kasım 2014, Konya.

Devellioğlu, F. (2010). Osmanlıca-Türkçe ansiklopedik lûgat. Ankara: Aydın Kitabevi Yayınları.

Ediskun, H. (1992). Türk dilbilgisi. İstanbul: Remzi Kitabevi Yayınları.

Efendioğlu, S. (2013). Vâhidî, Cinânü'l-cenân, (giriş, dil İncelemesi, metin, dizinler). Erzurum: Fenomen Yayınları.

Efendioğlu, S., İşcan, A. (2010). Türkçe ses bilgisi öğretiminde ses olaylarının sınıflandırılması. Atatürk Üniversitesi Türkiyat Araştırmaları Enstitüsü Dergisi, 43, 121-143.

Eker, S. (2010). Çăgdaş Türk dili. Ankara: Grafiker Yayınevi.

Ercilasun, A. B. (1985). Doğu Anadolu ağızlarının sınıflandırılması. Türk Kültürü Araştırmaları Dergisi, İbrahim KAFESOĞLU Armă̆anı, Ankara, 379-387.

Ercilasun, A. B. (2002). Kars ili ağızları (ses bilgisi). Ankara: TDK Yayınları.

Eren, H. (1999). Türk Dilinin etimolojik sözlüğ̈̈. Ankara.

Fasmer, M. (1987). Etimologiçeskiy slovar Russkogo yazıka (Rusçanın etimolojik sözlügü). IV Tom, Progres, Moskova. 
Gemalmaz, E. (1982). Standart Türkiye Türkçesi (STT)'nin formanlarının enformatif değerleri ve bu değerlerin ihtiyaç halinde bu dilin gelişimine muhtemel etkileri. Erzurum.

Gemalmaz, E. (1995). Erzurum ili ağızları (inceleme-metinler-sözlük ve dizinler). 3 Cilt, Ankara: TDK Yayınları.

Gemalmaz, E. (1997). Türkçede tamlanan eki üzerine. Atatürk Üniversitesi Türkiyat Araştırmaları Enstitüsü Dergisi, 8, 1-5.

Gemalmaz, E. (1999). Türkiye Türkçesinde ses olayları. Atatürk Üniversitesi Türkiyat Araştırmaları Enstitüsü Dergisi, 13, 1-27.

Gemalmaz, E. (2010). Türkçenin derin yapısı. (Hazırlayanlar: Alyılmaz, C. ve Mert, O.), Ankara: Belen Yayınları.

Gülensoy, T. (2007). Türkiye Türkçesindeki Türkçe sözcüklerin köken bilgisi sözlüğü. 2 Cilt, Ankara: TDK Yayınları.

Güllüdağ, N. (2009). Artvin ağzındaki Gürcüce kelimeler. Türkiye Türkçesi A ̆gız Araştırmaları Çalıştayı Bildirileri, Şanlıurfa, 2008. Ankara: TDK Yayınları, 237-250.

Ilıcalı, N. (1995). Erzurum Ağzl. Erzurum: Ergenekon Kitap Kırtasiye Yayınevi.

Karaağaç, G. (2008). Türkçe Verintiler Sözlüğü. Ankara: TDK Yayınları.

Karaca, V. (2011). Türkiye Türkçesinde alıntı sözcüklerde görülen ses olayları üzerine bir inceleme. Yayımlanmamış yüksek lisans tezi, Elazığ: Fırat Üniversitesi Eğitim Bilimleri Enstitüsü.

Karahan, L. (1996). Anadolu ă̆ızlarının sınıflandırılması. Ankara: TDK Yayınları.

Kırzıoğlu, M. F. (1962). Lehçe-i Erzurum yazmasındaki halk sözleri. Türk Dili Araştırmaları Ylllı̆̆ , Belleten, Ankara: TDK Yayınları, s. 195-243.

Korkmaz, Z. (1994). Güney-Batı Anadolu ağızları ses bilgisi (fonetik). Ankara: TDK Yayınları.

Korkmaz, Z. (2003). Gramer terimleri sözlüğ̈̈. Ankara: TDK Yayınları.

Kurat, A. N. (1987). Rusya tarihi (başlangıçtan 1917’ye kadar). Ankara: TTK Yayınları.

Kurat, Y. T. (1999). 1878-1919 arasında Türk-Rus ilişkilerinin siyasal anatomisi. Türk-Rus Illişkilerinde 500 Yll, 1491-1992, Ankara: TTK Yayınları, s.139-145.

Miklosich, H. F. (1889). Die Slavischen-Magyarischen und Rumanischen elemente im Turkischen sprach schatze. Wien.

Mustafaev, E., Şçerbinin, V. G. (1996). Büyük Rusça-Türkçe Sözlük. İstanbul: Multilingual Yayınları.

Nişanyan, S. (2007). Sözlerin soyağacı, çağdaş Türkçenin etimolojik sözlüğü. İstanbul: Adam Yayınları.

Olcay, S. (1995). Erzurum ă̆zı (inceleme-derleme-sözlük), Ankara: TDK Yayınları. 
$178^{*}$ TAED 55

Muharrem DAŞDEMiR - Süleyman EFENDiOĞLu

Olcay, S. (1998). Arpaçay köylerinden derlemeler. Ankara: TDK Yayınları.

Öksüz, Y. Z. (1995). Türkçenin sadeleşme tarihi: genç kalemler ve yeni lisan hareketi. Ankara: TDK Yayınları.

Özeren, M. (2014). Türkiye Türkçesi ağızlarındaki Rusça sözcükler. Turkish Studies, International Periodical For The Languages, Literature and History of Turkish or Turkic, 9/3, 1093-1120.

Radloff, W. (1960). Türk lehçeleri sözlüğü denemesi. 4 Cilt, Sank-Peterburg / Rusya, 1911 (T1pkıbasım, Gravenhage, 1960).

Sağır, M. (1995). Erzincan ve yöresi ağızları (inceleme-metinler-sözlük). Ankara: TDK Yayınları.

Sevortyan, E. V. (1974). Türk dillerinin etimolojik sözlüğ̈̈. 5 Cilt, Moskova.

Sezen, L. (2007). Erzurum folkloru. Erzurum: Atatürk Üniversitesi Yayınları.

Süleymanoğlu Yenisoy, H. (1998). Tarih boyunca Slav-Türk dil ilişkileri (Türkçede ve öteki Türk lehçelerinde slav leksik unsurlarl). Ankara: TDK Yayınları.

Şemsettin, S. (1989). Kamus-ı Türkî. Enderun Kitabevi, İstanbul, 1989.

Şipova, Y. N. (1976). Slovar Tyurkizmov v Russkom yazıka (Rus dilindeki Türkçe unsurlar sözlü̈̆̈̈). Alma-Ata.

Tietze, A. (1957). Slavische lehnwörter in der Turkischen volkssprache. Oriens X.

Tietze, A. (2010). Tarihî ve etimolojik Türkiye Türkçesi lügati. 2 Cilt (A-E; F-J), İstanbul: Simurg Yayınları.

Türk Dil Kurumu. (2009). Tarama sözlügü̈. 8 Cilt, 4. Baskı, Ankara: TDK Yayınları.

Türk Dil Kurumu. (2009). Türkiyede halk ağzından derleme sözlüğü. Birleştirilmiş Tıpkıbasım, 6 Cilt, Ankara: TDK Yayınları.

Türk Dil Kurumu. (2011). Türkçe sözlük. 11. Bask1, Ankara: TDK Yayınları.

Türk Dil Kurumu. (2012). Yazım kılavuzu. 27. Bask1, Ankara: TDK Yayınları. 